\title{
Special issue: entrepreneurship and education-links between education and entrepreneurial activity
}

\author{
Mário Raposo • Arminda do Paço
}

Published online: 7 April 2010

(C) Springer Science+Business Media, LLC 2010

The importance of individual entrepreneurial activity to economic growth and well-being at national level, for both industrialized and developing countries, is well established and supported by different reports. Relevant research suggests important links between education, venture creation and entrepreneurial performance. Therefore, the study of the precursors of the entrepreneurial activity offers important insights of the educational impact. To the extent that education can provide a greater supply of entrepreneurs and higher levels of entrepreneurial performance, its impact presents several important policy questions, so appropriate investments are justified by the governments.

The definition of entrepreneurship education, adopted at European level, stresses that this concept is much wider than just "training on how to start a business". Entrepreneurship is firstly a mindset. As attitudes take shape at an early age, school education can greatly contribute to fostering entrepreneurial mindsets, starting from primary school to the University level.

The growth of entrepreneurship education, and the associated research regarding the impact of such education, arise interesting challenges both to institutions delivering entrepreneurship education and for supporting organizations. Although the findings about the link between entrepreneurial education and entrepreneurial activity are not definitive, there is significant research suggesting this linkage.

This special issue of the International Entrepreneurship Management Journal includes eight papers, theoretical and empirical, on several aspects and factors that explain why entrepreneurship education is considered a key competence to young people. The authors here presented also underline the impact of education on entrepreneurship and entrepreneurial performance.

The first paper, conceptual in nature, provides an introduction to the problematic of "teachability" of entrepreneurship. Heiko Haase (University of Applied Sciences Worms) and Arndt Lautenschläger (University of Applied Sciences Jena), both from

\footnotetext{
M. Raposo $\cdot$ A. do Paço $(\bowtie)$

Department of Business and Economics, NECE (Research Unit in Science Business),

University of Beira Interior, Covilhã, Portugal

e-mail: apaco@ubi.pt
}

M. Raposo

e-mail: mraposo@ubi.pt 
Germany, promote a scientific discussion on this pedagogical aspect and conclude that future entrepreneurship education should desist from merely teaching knowledge on business creation and rather focus on experiencing entrepreneurship.

Next, Dev Dutta, Jun Li and Michael Merenda from the University of New Hampshire, present a research that aims to enhance the understanding of how prospective entrepreneurs benefit from specialized entrepreneurship education combined with a diversified educational experience. They found evidence that depth or specialization of entrepreneurship education is not enough for wealth creation.

By its turn David Kirby and Nagwa Ibrahim from the British University in Egypt (Cairo) examine the Entrepreneurial Tendencies of students of business administration at the British University in Egypt using the Durham University General Enterprising Tendency Test. Their study emphasise the brain dominance of the students and makes proposals for future research.

Following three papers are mainly focuses in the field of entrepreneurship intentions. Thus, Francisco Liñán, Juan Rodríguez-Cohard and José Rueda-Cantuche, respectively from the Universidad de Sevilla, Universidad de Jaén and Universidad Pablo de Olavide, (Spain), provide empirically-based suggestions for the design of improved entrepreneurship education initiatives. The empirical analysis is based on two essential elements: firstly, an already validated instrument (EIQ); secondly, a statistical method (factor-regression procedure) which is not dependent on any theoretical approach.

Fifth paper presented by Olivier Giacomin, Frank Janssen, Mark Pruett, Rachel Shinnar, Francisco Llopis and Bryan Toney from Belgium (Université Catholique de Louvain), USA (Appalachian State University) and Spain (University of Alicante), question if entrepreneurship education is the same in every country or should it be adapted to each context. They examine whether differences exist among American, Asian and European students in terms of entrepreneurial intentions and dispositions, as well as motivations and perceived barriers for business startup.

José Sánchez García, from University of Salamanca (Spain), tests the effect of entrepreneurship education programmes on the entrepreneurial competencies and intention of university students in order to confirm (or disconfirm) conventional wisdom that entrepreneurial education increases the intention to start a business. The results showed that students in the 'programme' group increased their competencies and intention towards self-employment, whereas students in the control group did not.

The seventh paper focuses an interesting topic intending to evaluate the contribution of yoga to the entrepreneurial potential of university students. Carla Marques (University of Trás-os-Montes and Alto Douro), João Ferreira, Ricardo Gouveia Rodrigues (both from University of Beira Interior) and Mariza Ferreira, all from Portugal, using a SEM approach, analyse the characteristics associated with entrepreneurs and yogis, seeking to understand the personal attributes and the psychological and cognitive predispositions of both groups.

The last paper (Torben Bager, University of Southern Denmark) refers to a camp model for entrepreneurship teaching. The author shows that a camp site can be an efficient way for team building, creativity training and innovation boosting purposes. By means of in-depth studies of three quite different camps, all demonstrating convincing results, the learning outcomes, pedagogies and principles for camps are identified and discussed. 